\title{
Informing our successors: what botanical information for Santa Cruz Island will researchers and conservation managers in the century ahead need the most?
}

\author{
John M. Randall 1 , , Kathryn McEachern 2 , John Knapp1, Paula Power ${ }^{3}$, \\ Steve JunaK ${ }^{4}$, Kristina Gill ${ }^{4}$, Denise Knapp ${ }^{4}$, and Matt Guilliams ${ }^{4}$ \\ 1 The Nature Conservancy, California Chapter, 201 Mission Street, San Francisco, CA 94105 \\ ${ }^{2}$ U.S. Geological Survey, WERC, Channel Islands Field Station, 1901 Spinnaker Drive, Ventura, CA 93001 \\ ${ }^{3}$ National Park Service, Channel Islands National Park, 1901 Spinnaker Drive, Ventura, CA 93001 \\ ${ }^{4}$ Santa Barbara Botanic Garden, 1212 Mission Canyon Road, Santa Barbara, CA 93105
}

\begin{abstract}
Climate changes are predicted to drive changes in plant species composition and vegetation cover around the world. Preserved specimens and other botanical information that we gather today-a period future practitioners may look back on as an early stage of modern anthropogenic climate change-will be of value to conservation managers and conservation biologists in the decades and centuries ahead. Here, we present suggestions for the systematic collection, long-term curation (in museums, herbaria, and other research institutions), and maintenance of plant specimens, along with associated data and analyses on the plants and vegetation present today and in the past. The primary aim of this systematic survey is to provide information of high value to conservation researchers and managers both in the near term (the next several years) and through the century to come. Such a systematic survey would build on a strong foundation of research and adaptive management on the island. It would fill gaps in less well-studied groups of organisms and identify environmental, ecological, and cultural factors related to current patterns of distribution. It would also archive previously collected data, photographs, and other materials which would otherwise gradually degrade and become inaccessible. As a case study, we use Santa Cruz Island, California, which is managed for conservation. We are confident that the same approach may be applied to other lands and waters around the world. We argue that there is a particular need to collect and archive herbarium specimens and seeds from today's populations, activities largely overlooked in recent decades. We encourage conservation researchers and managers to consider what information will be most important for future managers and to help launch studies, monitoring programs, and collections to prepare their successors for success.
\end{abstract}

RESUMEN.-Se predice que los cambios climáticos generan variaciones en la composición de las especies vegetales y en la cobertura vegetal al rededor del mundo. Los especímenes preservados y la información botánica reunida a la fecha (un período que los futuros profesionales podrán percibir como la etapa temprana del cambio climático antropogénico moderno) pueden ser valiosos para los gestores y biólogos de la conservación de las décadas y de los siglos futuros. En este trabajo presentamos sugerencias acerca de la recolección sistemática, preservación y mantenimiento de los especímenes de plantas, así como datos, análisis sobre la vegetación actual y del pasado, además de su conservación a largo plazo en museos, herbarios y otras instituciones dedicadas a la investigación. El principal objetivo de este estudio sistemático es generar información relevante para los investigadores y los gestores de la conservación, tanto a corto plazo (años) como a largo plazo (próximo siglo). Usamos como estudio de caso la isla Santa Cruz (California), la cual es administrada para la conservación. Confiamos en que el mismo enfoque puede aplicarse en otras tierras y aguas de todo el mundo. Tal estudio sistemático construiría una base sólida de investigación y de gestión adaptativa de la isla. Lo anterior, ayudaría a recabar mayor información sobre los grupos de organismos menos estudiados e identificar los factores ambientales, ecológicos y culturales relacionados a los patrones actuales de distribución. También, permitiría archivar datos, fotografías y otros materiales previamente recolectados que, de otra manera, se deteriorarían gradualmente volviéndose inaccesibles. Argumentamos que existe una necesidad particular de recolectar y archivar especímenes de herbario y semillas de poblaciones actuales, actividades ampliamente ignoradas en las décadas recientes. Incitamos a los investigadores y a los gestores de la conservación, a seleccionar la información que consideran más importante para los futuros gestores y ayudar a impulsar estudios, a monitorear programas y fondos para preparar a sus sucesores para el éxito.

*Corresponding author: jrandall@tnc.org

JMR (D) orcid.org/0000-0003-2254-0385

KG (1) orcid.org/0000-0001-5996-366X

KM

DK orcid.org/0000-0003-2631-8247

orcid.org/0000-0002-4213-6032
JK

MG orcid.org/0000-0001-7112-6661

orcid.org/0000-0003-3919-8432 
Climate changes predicted over the coming decades will drive changes in species distributions, natural community composition and structure, and ecological processes around the world. This dynamism makes information about these factors as they are today, and as they have been in the past, even more valuable for researchers, land and water managers, and other decision makers than it would have been under a more stable climate (Higgs et al. 2014, Morrison et al. 2017, 2018). We are confident that the systematic collection, longterm curation (in museums, herbaria, and other research institutions), and maintenance of plant specimens, along with associated data and analyses on the plants and vegetation present today and in the past (hereafter "systematic survey") will be of great value to our successors in conservation biology and management. This perspective views these specimens and data as valuable, irreplaceable resources that will likely increase in value with time (Sutter et al. 2015). A systematic survey would be valuable whether our successors elect to manage for resilience to prolong the viability of populations, species, and communities present today, or whether they seek to accommodate or guide transitions to natural community compositions and conditions that no one alive today would recognize (i.e., "no-analog communities" sensu Williams and Jackson 2007). If our successors manage for resilience, this information will provide valuable baselines for setting conservation goals and managing toward achieving them; if they take the latter approach, detailed knowledge of where a given system has been will be invaluable for projecting the paths it may take and where it may go. With either approach, it will be valuable to gather and archive repeat data from a suite of reference sites over time so that vegetation change can be systematically documented, understood, and used to guide transitions for other areas as described by Hiers et al. (2012). For example, data taken from a suite of vegetation and substrate sample plots scattered across Santa Cruz Island (McEachern 1998, 2000, McEachern et al. 1997, 2010), or from the National Park Service's long-term vegetation monitoring program (Fancy et al. 2009), can be used to gauge the directions and rates of vegetation change across many island settings.

California's Channel Islands are all managed, at least in part, for nature conservation, and we anticipate that this management direction will continue for the foreseeable future. Information on past and current (early 21st century) biota and ecological processes will be of great value to our successors in research and conservation management over the coming century and beyond. Many of us have observed that this kind of information is often gathered in response to crisis situations. For example, following the discovery of steep declines in island fox (Urocyon littoralis) populations, information on fox population dynamics, fox predators, their predation rates under different scenarios, and several other factors were assembled very quickly to guide efforts to staunch the decline and launch a recovery (Bakker et al. 2009, USFWS 2012). If climate change plays out as predicted over the coming decades, we anticipate what could be thought of as a slow-motion crisis for nature conservation on and around the islands, and elsewhere across the world. In this case, however, we have an opportunity to plan and carry out a systematic effort to fill gaps in our knowledge and then use that information to understand and manage natural systems, shifting our strategy from that of crisis management to forethought and adaptation.

In 2016 we participated in 2 workshops and follow-up discussions in which we considered the value of launching a systematic survey to gather and preserve specimens, data, and data analyses on the biota and environmental characteristics of the islands. We concentrated on Santa Cruz Island to keep our scope tractable and our efforts efficient, but our findings could easily be extended to encompass the other Channel Islands. Our group (the 8 authors of this article) focused on terrestrial and freshwater plants. We addressed 3 questions: (1) What specimens, data, and analyses are needed to better document current botanical conditions? (2) What specimens, data, and analyses are needed to better document past botanical conditions? (3) How can we best preserve and glean information from plant specimens and other materials that have been or soon will be collected to inform conservation decisions? Three other groups participated in the workshops with emphasis on the following areas of study: terrestrial and freshwater animals (Boser et al. 2018); archaeological, paleobiological, and cultural resources (Rick et al. 2018); and marine biota in the 
waters surrounding the islands (Gleason et al. 2018). The collective enterprise, and the program of work it proposes, has tentatively been titled "Island Rediscovery" (Morrison et al. 2018).

A great deal is already known about the plants, vegetation, and ecological conditions on Santa Cruz Island and the rest of the Channel Islands, but large gaps remain and specimens of many native and introduced plant species were last gathered many decades ago. Channel Islands National Park, which encompasses 5 of the 8 California Channel Islands and includes the $24 \%$ of Santa Cruz Island owned by the National Park Service, is a pilot program among the 270 National Park Service units included in the system-wide Inventory and Monitoring Program. As part of this program, vegetation on several of the park's islands has been sampled repeatedly using a consistent protocol since 1984. The Nature Conservancy, which owns and manages most $(76 \%)$ of Santa Cruz Island, has also carried out and facilitated research, survey, and monitoring efforts on a variety of native and introduced plants and on island vegetation communities. The Santa Cruz Island Field Station of the University of California Natural Reserve System has hosted researchers for over 50 years and facilitated far more research on the island than would have otherwise been possible. The U.S. Navy, responsible for San Nicolas and San Clemente Islands, and the Catalina Island Conservancy, responsible for most of Santa Catalina Island, have likewise carried out and facilitated research, survey, and monitoring efforts. In all cases, however, there are gaps in in the taxonomic groups covered by these programs, and there have been long periods when little or no data were gathered by some of these programs, even for the highest-profile plant species and communities. In addition, much of the information gathered on the islands over the past century and earlier is scattered and difficult to access. This information includes photographs that could illuminate changes in vegetation, as well as plant and soil specimens that could be analyzed with new techniques to yield information on genetic relationships, change over time, and a suite of other factors.

We argue that these information gaps seriously hinder management today and will continue to do so in the future. We unanimously and strongly suggest the planning and implementation of systematic surveys to gather, organize, analyze, and archive data and specimens from Santa Cruz Island. Further, we suggest expanding the systematic survey to encompass the entire Channel Islands archipelago. We envision this systematic survey as a multi-institutional, collaborative effort to gather data, specimens, and other information. Below we outline our proposal for the terrestrial plant component of Santa Cruz Island, which embraces not just vascular plants but also nonvascular terrestrial plants, fungi, lichens, and the vegetation communities they comprise. Our proposal was developed with a primary question in mind: If we were responsible for the conservation of Santa Cruz Island a century from now, in 2120, what information would we want to have about the island's plants and vegetation from 100 years before and earlier? We encourage all conservation researchers and managers to consider this question and to identify research avenues that would address it.

\section{Focal AREa}

Santa Cruz Island is the largest of the 8 California Channel Islands $\left(249 \mathrm{~km}^{2}\right)$ and is located in the Pacific Ocean approximately $40 \mathrm{~km}$ south of Santa Barbara, California. It is home to at least 21 single-island endemic animal taxa (insects, reptiles, birds, and mammals) and 8 single-island endemic plant taxa (Junak et al. 1995, Schoenherr et al. 1999). It also supports many other Channel Islandsendemic species not found on the mainland, as well as endemic plant communities and many plant communities now uncommon on the California mainland. More detailed descriptions of Santa Cruz Island and its geology, flora, and natural history can be found in Junak et al. (1995), Weigand (1998), Schoenherr et al. (1999), and Rick et al. (2014).

\section{Climate Change Projections and Impacts on the IsLand's Plants and Vegetation}

Increases in atmospheric $\mathrm{CO}_{2}$ levels, mean annual temperatures, sea levels, and other factors measured over the past few decades indicate that anthropogenic climate change is already occurring in California and globally (Millar et al. 2007, Staudinger et al. 2013). Many models project increasing rates 
of climatic changes and sea level rise for a century or more (Cayan et al. 2008a, 2008b, Levermann et al. 2013, IPCC 2014). These changes are expected to have significant effects on the growth, reproduction, and distribution of plants and the animals, fungi, and other organisms they interact with. For example, Loarie et al. (2008) projected that with anticipated climate change, up to $66 \%$ of California's nearly 2400 endemic plant taxa will experience $80 \%$ reductions in range size within a century. Furthermore, a study of vegetation around the San Francisco Bay area (Ackerly et al. 2015) found that the sensitivity of vegetation to climate change was higher closer to the coast, in cooler areas (e.g., north-facing slopes), and in areas with greater precipitation. The vegetation of the Channel Islands may be similarly sensitive to climate change. Marine low clouds and fog, colloquially referred to as the marine layer, are important for the distribution of many plants on the Channel Islands and elsewhere in coastal California (Williams et al. 2008, Fischer et al. 2009, 2016, Carbone et al. 2012, Baguskas et al. 2014). The marine layer has apparently decreased in temporal and spatial extent over mainland Southern California since the mid1900 s, and this decrease is correlated with increases in urban cover (Williams et al. 2015). However, it is not clear whether there have been similar changes in the marine layer over the Channel Islands or whether changes in marine layer frequency, duration, elevation, and spatial extent can be expected in the future (Johnstone and Dawson 2010, Baguskas et al. 2014, Williams et al. 2015).

Cayan et al. (2009) projected a sea level rise of 35-45 cm between the years 2000 and 2050 , and $80-120 \mathrm{~cm}$ by 2100 . Cayan et al. $(2008 \mathrm{~b}$, 2009) also projected an increased rate of extreme high sea level events that occur during the highest tides (king tides), particularly those coinciding with winter storms that drive waters toward the coast. These events could inundate the Channel Islands' relatively small and rare coastal wetlands, dramatically increase the rate of sea cliff erosion, expose larger areas to salt spray, and be fatal to plants whose habitats are restricted to coastal bluffs and lowlying nearshore areas. These plants include the Santa Cruz Island endemic Dudleya nesiotica (federally listed as Threatened) and the Northern Channel Islands endemic Mala- cothrix indecora (federally listed as Endangered). Furthermore, rising sea levels and extreme tides threaten to erode ancient coastal Chumash habitation sites, which contain valuable historical ecological data that dates back millennia and can inform us about past vegetation communities and how they responded to climate change (see Rick et al. 2018).

As the climate warms, conditions will likely become unsuitable for some of the plant species now present on the island, and at the same time more suitable for species from the mainland or other islands that are already well adapted to these new conditions but which have not yet established on Santa Cruz Island. However, the physical isolation of Santa Cruz Island from the mainland and other islands is likely to limit natural immigration by species adapted to the new conditions. Likewise, the island's physical isolation will likely limit the ability of its plants, including endemic taxa, to migrate to other areas where the changed climate conditions may be more appropriate for them. These factors complicate the identification of appropriate management goals and conservation strategies for at least some of the taxa present today and for the vegetation communities on the island in the future. In light of the deep history of anthropogenic translocations on these islands (see Hofman and Rick 2018, Rick et al. 2019), our successors may consider translocating island endemic taxa to sites on the mainland and translocating new species to the island that are adapted to warmer, drier habitats than are present on the island today.

\section{Santa Cruz Island Land Management Objectives in the Future}

We assume that Santa Cruz Island will remain in conservation ownership and that the core values of Santa Cruz Island's future conservation managers will be similar to values held today. These values include a focus on maintenance and protection of native species, communities, and ecological processes. However, we suspect that as climate change progresses there may be changes in what is regarded as native to any given site, at least on the mainland. For example, conservation managers may come to accept as "native" those species that migrate or are translocated from more southern or lower-elevation sites, particularly because such acceptance would 
allow these plants to track their climatic niches and avoid extinction. Changes in climate and resultant type-conversion of vegetation and habitats on the mainland may also lead the public to assign even greater value to Santa Cruz Island and other sites that can preserve at least some of the native species and vegetation types that are present today. Our management successors and the public may also assign the island even greater value than we do today as one of the rare places where biological change can proceed with minimal interference from modern human land uses that are common on the mainland (e.g., residential development, roads, livestock, agriculture, etc.).

Today we value the island's native flora and vegetation but recognize that climate change will likely have significant and perhaps transformational effects. We expect that in decades to come our successors will be faced with difficult and complex decisions regarding how to manage and protect the flora and vegetation. Based on our experience, we anticipate that our successors will be in the best position to face these management decisions if they are armed with detailed information about the island's flora and vegetation today and in decades, centuries, and millennia past. Therefore, we suggest that researchers and managers launch a systematic survey now to monitor, study, and collect specimens and data on the flora, vegetation, and environmental conditions of today. Likewise, we suggest the launch of an allied systematic survey to compile and ensure the accessibility of information that will illuminate past conditions, including paleobotanical and archaeobotanical studies as well as data and specimens gathered decades ago. In addition, we suggest that the data and information compiled in these efforts be archived in a format that ensures public accessibility in perpetuity. Below, we outline the types of specimens, data, and analyses that we believe are of greatest importance. These examples are undoubtedly not complete, but we hope that they inspire the launch of a systematic body of work, with collections and databases that are easily and permanently accessible.

\section{Documenting the Present}

The systematic survey we suggest for documenting the present would build on a strong foundation. As of June 2018, herbaria in California held at least 20,900 specimens collected on Santa Cruz Island, the earliest dating back to 1874 (data provided by the participants of the Consortium of California Herbaria, see ucjeps.berkeley.edu/consortium). A Flora of Santa Cruz Island (Junak et al. 1995) provides an excellent summary of all vascular plant taxa known from the island by the mid-1990s, including information on distribution, flowering times, and habitats, in addition to taxonomic descriptions and fine pen-and-ink illustrations. More recent studies have been published on the taxonomic relationships and ecology of many of the island's native and introduced plants. Repeated surveys for several of the island's federally listed and other rare species were carried out in the late 1970s, mid-1990s, mid-2000s, and again in 2015-2016 (Hochberg et al. 1980, McEachern et al. 1997, 2010, Knapp in preparation). Likewise, there have been a variety of studies of plant-bird and plant-insect interactions on the island (e.g., Thorp et al. 1994, 2000, Barthell et al. 2001, 2005, Pesendorfer 2014, Hanna et al. 2015, Langin et al. 2015, Pesendorfer et al. 2017). Minnich (1980), Jones et al. (1993), and Cohen et al. (2009) created vegetation maps of the island, and an updated vegetation map based on field data collected in 2015/2016 will be completed in 2019 (Knapp and Rodriguez in preparation). Studies of significant and large-scale changes in vegetation in response to drought and other factors have also been carried out, including studies of periodic die-backs of the island's bishop pine (Pinus muricata) forests (Wehtje 1994, Walter and Taha 2000, Fischer et al. 2009, Baguskas et al. 2014). The studies listed here are just a small sampling of published Santa Cruz Island-based plant research; additional data from unpublished studies are also available. For an extensive review of these studies, see Davidson et al. (2014) chapter 4.3.

Despite the strong foundation of previous work, there are still major gaps in what is known about the flora and vegetation of Santa Cruz Island; many collections and data are now dated. In addition, the island's flora and vegetation have undergone significant changes over the past several decades. Recovery of the flora, particularly recovery of woody plant cover, has been remarkable since the end of the ranching era and the subsequent eradication of thousands of feral sheep (Ovis aries) 
and over 5000 feral pigs (Sus scrofa) by the mid-2000s (Morrison 2007, 2011, Beltran et al. 2014). Over a century of grazing and browsing by these introduced species and by introduced cattle (Bos taurus) significantly reduced recruitment of new trees and shrubs and left large areas of the island devoid of plant cover and subject to heavy erosion (Van Vuren and Coblentz 1987, Pinter and Vestal 2005, Perroy et al. 2010, Beltran et al. 2014, Gill et al. 2019). Unfortunately, however, relatively few plant specimens have been collected over the past few decades as the island's plants and vegetation have been recovering. Just 110 of the 20,900 herbarium specimens $(0.5 \%)$ from the island have been collected since 2010 , and only $336(<2 \%)$ have been collected since 2000 (data provided by the participants of the Consortium of California Herbaria, see ucjeps.berkeley.edu/consortium). Likewise, the most authoritative source on the island's plants, A Flora of Santa Cruz Island (Junak et al. 1995), was published nearly a quarter century ago, a full decade before feral pigs were eradicated from the island. Since the mid-1990s, significant changes in the distributions of many species and plant communities have been documented, including documentation of an additional 10 native and 25 nonnative plant taxa on the island. Notwithstanding excellent recent work on the island's lichen flora (Knudsen and Kocourková 2012, Knudsen et al. 2014) and bryophyte flora (Carter 2015), much remains to be learned about these groups as well. Furthermore, the island's fungi are currently even less well known.

The Value of Herbarium Specimens

for Documenting the Past and Present and Informing the Future

The paucity of recent herbarium specimens is of particular concern (Suarez and Tsutsui 2004). Herbarium specimens are critical for preserving a record of the presence and location of a plant species at any given time, addressing questions about taxonomy, nomenclature, and phylogeny, and identifying new taxa or justifications for lumping taxa (Taylor and Swann 1994, Bebber et al. 2010). Herbarium specimens can also yield genetic information, which can then be compared to address questions about evolution, the function and origin of genes, and the changing genetic structures of populations (Herrmann and Hummel 1994, Taylor and Swann 1994, Ristaino 1998, Holmes et al. 2016). They have been used to reconstruct the history of the arrival and spread of nonnative and native species (Delisle et al. 2003, Chauvel et al. 2006, Lavoie et al. 2007) and to illuminate the history of plant diseases and the genetics and evolution of plant pathogens, as well as the commensal and mutualistic microorganisms that live in and on plants (Fraile et al. 1997, Ristaino 1998). Furthermore, herbarium specimens may yield information on an array of environmental factors and how they have changed over time. For example, Woodward (1987) compared the densities of stomata on herbarium specimens of 8 different tree species collected over the past 200 years and found that they had declined by $40 \%$, increasing the water use efficiency of these plants, likely in response to increases in atmospheric $\mathrm{CO}_{2}$ over that time. Herbarium specimens have also been used to document changes in phenology of plants over time (Primack et al. 2004, Miller-Rushing et al. 2006, Calinger et al. 2013). As with all archived plant and animal material collections, the development of new paradigms, technologies, and techniques in the future will further increase the value to our successors of specimens collected and preserved today (Lavoie 2013). For instance, recent groundbreaking research on the abundance, ubiquity, and integration of microorganisms on and in higher organisms suggests that it may be most appropriate to treat plants as biomolecular networks composed of the host plant and its associated microbes (Bordenstein and Theis 2015). Herbarium specimens could help illuminate how these biomolecular networks, or "holobionts," and their "hologenomes" have changed over time.

\section{Suggestions for Documenting the Present}

We suggest the launch of a systematic survey to collect plant specimens and fresh seeds, monitor distribution and abundance of taxa (especially those deemed high priorities), and inform studies needed to fill important gaps. This effort is intended as part of a larger suite of inventories under the proposed title of "Island Rediscovery," which will encompass terrestrial and freshwater animals, marine biota in the waters around the island, and archaeological, paleobiological, and cultural resources, 
as well as terrestrial plants and vegetation (Boser et al. 2018, Gleason et al. 2018, Morrison et al. 2018, Rick et al. 2018). This systematic survey could involve researchers and conservation managers from various agencies, nonprofit organizations, and private firms.

Important questions about the island's flora, vegetation, and drivers of change include the following:

- How are native and nonnative plant taxa distributed, and how abundant are they on the island today? How has this distribution changed over the past 3 decades? When was each nonnative taxon first recorded on the island?

- Which vegetation types (associations and alliances) are present on the island and how are they distributed? How have these vegetation types and distributions changed over time?

- What are the most important physical and environmental factors underlying the distribution and abundance of the island's flora and vegetation?

- Which climate variables should we measure now so that changes can best be detected and characterized in the decades ahead?

- What are the dominant interactions with animals and other organisms (including microorganisms), particularly for rare and indicator plant taxa?

- What are the roles of fog and fire in the reproduction and survival of native versus invasive plants and the distribution of vegetation types?

- How do the island's current land uses and disturbance regimes affect the distribution and abundance of the flora and vegetation? How do these patterns differ from patterns under the prior ranching/agricultural and Chumash land-use eras?

- How did the most recent 5-year drought, from 2011 to 2016, affect the distribution and abundance of native and invasive taxa and vegetation types? How do the effects of this drought compare to the effects of earlier droughts?

- How has the recent severe die-back of adult bishop pine trees affected this species' distribution and abundance? Was this die-back greater in extent than the die-back that accompanied the drought of the late 1980s/early 1990s?

- How has anthropogenic climate change already affected the distribution, abundance, reproduction, and ecological interactions of the island's plants?

To address these questions, we suggest that the following research and monitoring be conducted:

- Complete a California Islands Flora, with information on all vascular plants known to be present on the 8 Channel Islands, including current information on the distribution, abundance, and phenology for each taxon. A team of scientists at the Santa Barbara Botanic Garden has already launched this project (including coauthors M. Guilliams and S. Junak).

- Complete systematic surveys of Santa Cruz Island's nonvascular plants, macrofungi, and lichens, and publish results that include information on the distribution, abundance, and habitats of these organisms.

- Complete a systematic collection of new specimens of all native and nonnative plant taxa on the island and deposit the vouchers in herbaria; include vascular and nonvascular plants, macrofungi, and lichens.

- Develop a seed bank for the island's native plants.

- Develop a more robust weather and climate monitoring system for Santa Cruz Island, adding new stations at the western and eastern ends of the island, near the south and north shores, and at elevations above $300 \mathrm{~m}$.

- Continue to monitor the temporal and spatial distribution of fog and marine low clouds (the "marine layer") over the island, as described in Rastogi et al. (2016).

- Add vegetation transects on the portion of Santa Cruz Island owned by The Nature Conservancy, using the same methods used by the National Park Service on its portion of the island (McEachern 1998, 2000, Johnson and Rodriguez 2001). 
- Complete and publish results of the repeatphoto project undertaken on the island in 2015-2016 (Schuyler in preparation), and take repeat photographs from the same sites every 10 years to document changes in vegetation and other features.

- Acquire and archive aerial photography and remote sensing imagery for the island in a central database.

\section{Documenting The Past}

As part of "Island Rediscovery," we also suggest systematic, well-planned efforts to gather and archive specimens and data in existing collections and to gather new data to better document Santa Cruz Island's flora and vegetation in the past. Approximately $98 \%$ of the existing island herbarium specimens were collected between 1874 and 2000. These specimens provide a basis for addressing a variety of questions on taxonomy, ecology, and responses to trends in environmental and climatic factors during and after the historic ranching era (data provided by the participants of the Consortium of California Herbaria, see ucjeps.berkeley .edu/consortium). Many botanists and other naturalists who collected and worked on the island during this time left detailed notes and photographs, many of which have yet to be copied, compiled, or made readily available (Junak et al. 1995). Aerial photographs of the island dating back to the 1920s and satellite images starting in the 1970s could also yield greater insights into changes in the island's vegetation over the past century. These images are currently archived at the Maps and Imagery Laboratory at UC Santa Barbara, but have not yet been fully analyzed or integrated into GIS analysis of vegetation patterns through time. Archaeological and paleoethnobotanical data can also illuminate human use of native plants on the island and aspects of the vegetation dating back more than 10,000 years, before the introduction of Old World plants and animals and the cessation of native land management practices. The influence that Native land management strategies had on the development, composition, and distribution of island plant communities is not well understood but may have been significant. Carefully documenting patterns of human-plant interactions using archaeological and paleoethnobotanical data could provide a trans-Holocene perspective for how terrestrial island plant systems responded and adapted to changing environmental conditions and cultural practices (see Gill 2014, 2015, 2016, Gill and Hoppa 2016, Gill et al. 2019).

\section{Suggestions for Documenting the Past}

Some of the important questions to be addressed about Santa Cruz Island's past plants and vegetation communities and how they changed over time include the following:

- How has the island's vegetation changed over the past 10,000 years and longer?

- How has the island's vegetation changed since the 1540s, when European explorers first visited the area?

- Can we get a detailed, quantitative picture of how the island's vegetation has changed since the late 1700s, when Spanish settlement of California began?

- How significant were anthropogenic factors, including both active and passive activities conducted by the Chumash and their ancestors, in shaping the island's vegetation?

- How has the island's climate changed over the past 10,000 years and more?

- Did the Chumash introduce any plants from the mainland to the island? If so, which ones?

- What are all of the plant taxa definitively known to have occurred on Santa Cruz Island, based on specimens, photo documentation, fossils, etc.?

- Were there previous major die-backs of certain taxa due to disease, herbivory, or drought in the past that were akin to the ongoing bishop pine die-back?

- How many species have gone extinct or been extirpated from the island over time?

To address these questions, we suggest that the following research be conducted:

- Compile extant data and conduct additional paleoethnobotanical and archaeological studies from various time periods and areas of the island to provide an outline of changes in the island's vegetation over the past 10,000 years and more. 
- Combine information from paleoethnobotanical and archaeological studies, ship logs, historical photos (including aerials), naturalists' field notes, and other data to generate a more detailed and, where possible, a more quantitative picture of how the island's vegetation has changed from the 1540 s to the present.

- Compile information and preserve sediment cores used to evaluate climate change over the past 10,000 years and more.

- Conduct genetic studies on plant taxa that may have been intentionally introduced by the Island Chumash for specific cultural reasons, including food, medicine, fuel, tools, and rituals. Tese taxa include various oaks (Quercus spp.), Yerba Mansa (Anemopsis californica), tobacco (Nicotiana spp.), geophytes, etc.

- Examine archaeological and paleoethnobotanical data for evidence of the first appearance of plant taxa that might have been introduced to the island by the Chumash.

- Create a list of all plant taxa known to have occurred on the island in the past based on herbarium specimens, paleoethnobotanical remains, photo documentation, fossils and subfossils, etc., and list potential factors involved in their extinction/extirpation.

Suggestions for Managing and Archiving Data and Making Them Readily Available

Specimens and data gathered in a systematic survey of the plants and vegetation present on the island today and in the past must be documented and archived in a manner that will ensure they are available and useful to researchers and land managers over the coming century and longer. This would require that each project contributing to this systematic survey develop and record clear data collection and management protocols. Sutter et al. (2015) provide practical guidance on data collection and management for long-term ecological projects covering the following topics:

- planning and preparation for both the collection and management of data;

- selection and acquisition of data management infrastructure;

- roles and responsibilities of participants;
- training, selection, and development of data capture systems (e.g., selection of a citizen science application such as iNaturalist [https://www.inaturalist.org] or development of a custom data collection application);

- protocols for capturing and storing multimedia content such as imagery and acoustic recordings;

- data quality control and review;

- creation and storage of metadata;

- selection and development of databases or information systems to store and provide access to the data; and

- protocols for periodic data backup and for the possible need to transfer data to another information system in the years ahead as database technology proceeds and older systems are phased out.

To encourage digitization, upload, and archiving of field-collected specimens and data and to enhance access to this information, we recommend that all specimens and data collected and compiled as part of the systematic survey of plants and vegetation be archived in the California Islands Biodiversity Information System (Cal-IBIS; http://cal-ibis.org), which was created and is being maintained by a consortium of agencies, nonprofit organizations, and research institutions engaged in the conservation and study of the biota of the Channel Islands.

To ensure that the specimens and data collected in the systematic survey are relevant over the next century, during the collection planning phase we must consider the potential questions our successors may have 100 years from now (Morrison et al. 2017). For example, because we expect phenological changes in plants and behavioral changes in animals as the climate changes, recording the date, location, and time that observations are made or specimens are collected may prove particularly useful in future studies.

\section{Suggestions for Archiving Existing Data and Making Them Readily Available}

Large volumes of data, specimens, field notes, photographs, and other information illuminating the flora and vegetation of the recent to more distant past exist in various collections but have not yet been archived in a single database. These disparate data sets 
could further degrade or otherwise become unavailable with time; therefore, we suggest that the following efforts be made:

- Collect, digitize, and archive field notes of all botanists and other naturalists who collected plant specimens and made observations about vegetation on the island whose notes are not already archived.

- Update the NPSpecies database records for Santa Cruz Island. The NPSpecies database houses information on the completeness of vouchered floristic collections in national parks nationwide (https://irma.nps .gov/NPSpecies; Chess and McEachern 2001).

- Collect and archive oral histories of the work carried out by living botanists and other researchers who worked on the island's plants over many years, such as Sarah Chaney, Steve Junak, Robert Klinger, Peter Schuyler, Dirk Van Vuren, Nancy Vivrette, and Dieter Wilken.

- Solicit and archive photographs from private collections of naturalists, researchers, and others who have worked on the island.

- Solicit and archive field data collection locations from researchers who conducted botanical studies on the island (e.g., locations of sample plots, transect lines, etc.).

- Compile, maintain, and make accessible spatially explicit data on vegetation and the flora collected in the past, including paleoethnobotanical and fossil data, that can be cross-referenced with more recent observations.

\section{Concluding Remarks}

Santa Cruz Island's flora and vegetation have undergone significant changes over time and are expected to undergo further changes in the century ahead as the climate changes. Because the biota of Santa Cruz Island includes many endemic taxa, which are of high conservation value and great interest to researchers, we suggest that a systematic survey be launched and carried out over the next several years to archive existing materials and gather new specimens and information on the island's flora and vegetation. This survey would be of immediate interest and value to conservation managers, but our long-term goal is to provide high-value information to the conservation researchers and managers who succeed us a century from now. We have laid out an ambitious but achievable set of suggestions for gathering specimens and data and conducting key analyses and studies. Work is already underway for some of them, but most of the efforts suggested here have yet to be launched. Doing so would require additional funding and the participation of additional researchers and conservation managers. We hope that this paper and related "Island Rediscovery" papers inspire and attract the funding and logistical support necessary to achieve these goals. We believe that the successful implementation of a systematic survey of the plants and vegetation on Santa Cruz Island can serve as a case study for similar efforts across the California Channel Islands and in other important conservation areas around the world, all of which face a future in which significant climate change and subsequent floral and faunal changes are predicted.

\section{ACKNOWLEDGMENTS}

We gratefully acknowledge the Santa Barbara Natural History Museum and the 2016 California Islands Symposium organizing committee for hosting, and the Nature Conservancy for funding and organizing, the workshops where work on this paper started. This work builds on the efforts of many researchers and land managers who have collected data, carried out experiments, and recorded valuable observations on Santa Cruz Island's flora and vegetation. Thanks to all those who curated the resultant collections and information. The University of California's Santa Cruz Island Field Station has played an instrumental role in much of this research for the past 50 years. The use of trade, firm, or product names in this document is for descriptive purposes only and does not imply endorsement by the U.S. Government.

\section{Literature Cited}

Ackerly, D.D., W.K. Cornwell, S.B. Weiss, L.E. Flint, AND A.L. FLINT. 2015. A geographic mosaic of climate change impacts on terrestrial vegetation: which areas are most at risk? PLOS ONE 10:e0130629.

Baguskas, S.A., S.H. Peterson, B. Bookhagen, and C.J. STILL. 2014. Evaluating spatial patterns of droughtinduced tree mortality in a coastal California pine forest. Forest Ecology and Management 315:43-53. 
Bakker, V.J., D.F. Doak, G.W. Roemer, D.K. Garcelon, T.J. CoOnan, S.A. Morrison, C. LynCh, K. Ralls, AND R. SHAW. 2009. Incorporating ecological drivers and uncertainty into a demographic population viability analysis for the island fox. Ecological Monographs 79:77-108.

Barthell, J.F., J.M. Randall, R.W. Thorp, and A.M. Wenner. 2001. Promotion of seed set in yellow star-thistle by honeybees: evidence of an invasive mutualism. Ecological Applications 11:1870-1883.

Barthell, J.F., R.W. ThorP, A.M. Wenner, J.M. Randall, AND D.S. MitchelL. 2005. Seed set in a non-native self-compatible thistle on Santa Cruz Island: implications for the invasion of an island ecosystem. Pages 185-191 in D.K. Garcelon and C.A. Schwemm, editors, Proceedings 6th California Islands Symposium, Ventura, December 1-3, 2003. National Park Service Technical Publication CHIS-05-01, Institute for Wildlife Studies, Arcata, CA.

Bebber, D.P., M.A. Carine, J.R. Wood, A.H. Wortley, D.J. Harris, G.T. Prance, G. Davidse, J. Paige, T.D. Pennington, N.K. Robson, and R.W. Scotland. 2010. Herbaria are a major frontier for species discovery. Proceedings of the National Academy of Sciences 107:22169-22171.

Beltran, R.S., N. Kreidler, D.H. Van Vuren, S.A. Morrison, E.S. Zavaleta, K. Newton, B.R. TerShey, AND D.A. Croll. 2014. Passive recovery of vegetation after herbivore eradication on Santa Cruz Island, California. Restoration Ecology 22: 790-797.

BoRdensteIn, S.R., AND K.R. Theis. 2015. Host biology in light of the microbiome: ten principles of holobionts and hologenomes. PLOS Biology 13:e1002226.

Boser, C.L., T.S. Sillett, P.W. Collins, K.R. Faulkner, W.C. Funk, C.K. Ghalambor, L. Laughrin, G.B. Pauly, J.M. Robertson, R. Shea, and W. Vickers. 2018. Equipping tomorrow's historical ecologist: priorities for documenting conditions of the terrestrial fauna of Santa Cruz Island, California. Western North American Naturalist 78:879-887.

Calinger, K.M., S. Queenborough, and P.S. Curtis. 2013. Herbarium specimens reveal the footprint of climate change on flowering trends across north central North America. Ecology Letters 16:1037-1044.

Carbone, M.S., A.P. Williams, A.R. Ambrose, C.M. Boot, E.S. Bradley, T.E. Dawson, S.M. SchaefFER, J.P. SCHIMEL, AND C.J. STILL. 2012. Cloud shading and fog drip influence the metabolism of a coastal pine ecosystem. Global Change Biology 19:484-497.

Carter, B. 2015. A checklist of the bryophytes of the California Channel Islands. Madroño 62:186-207.

Cayan, D.R., P.D. Bromirski, K. Hayhoe, M.D. DetTINGER, AND R.E. Flick. 2008a. Climate change projections of sea level extremes along the California coast. Climatic Change 87(1):57-73.

Cayan, D.R., E.P. Maurer, M.D. Dettinger, M. Tyree, AND K. HaYhoe. 2008b. Climate change scenarios for the California region. Climatic Change 87(1): $21-42$.

Cayan, D.R., M. Tyree, M. Dettinger, H. Hidalgo, T. Das, E. Maurer, P. Bromirski, N. Graham, and R. FLICK. 2009. Climate change scenarios and sea level rise estimates for the 2009 California Climate Change Scenarios Assessment. California Climate Change Center. CEC 5002009014 F.
Chauvel, B., F. Dessaint, C. Cardinal-Legrand, and F. Bretagnolle. 2006. The historical spread of Ambrosia artemisiifolia L. in France from herbarium records. Journal of Biogeography 33:665-673.

Chess, K., and K. McEachern. 2001. Channel Islands National Park vascular plant voucher collections: NPSpecies database. National Park Service, Fort Collins, CO. https://pubs.er.usgs.gov/publication/96986

Cohen, B., C. Cory, J. Menke, and A. Hepburn. 2009. A spatial database of Santa Cruz Island vegetation. Pages 229-244 in C.C. Damiani and D.K. Garcelon, editors, Proceedings of the Seventh California Islands Symposium. Institute for Wildlife Studies, Arcata, CA.

Davidson, A.D., A.K. McEachern, T.J. Coonan, W.T. Bean, And A.J. Armstrong. 2014. Channel Islands National Park: natural resource condition assessment. Natural Resource Technical Report NPS/ CHIS/NRTR-2014/XXX. National Park Service, Fort Collins, $\mathrm{CO}$

Delisle, F., C. Lavoie, M. Jean, and D. Lachance. 2003. Reconstructing the spread of invasive plants: taking into account biases associated with herbarium specimens. Journal of Biogeography 30:1033-1042.

Fancy, S.G., J.E. Gross, and S.L. CarTer. 2009. Monitoring the condition of natural resources in US National Parks. Environmental Monitoring and Assessment 151:161-174.

Fischer, D.T., C.J. Still, C.M. Ebert, S.A. Baguskas, AND A.P. WiLliams. 2016. Fog drip maintains dry season ecological function in a California coastal pine forest. Ecosphere 7:e01364.

Fischer, D.T., C.J. Still, AND A.P. Williams. 2009. Significance of summer fog and overcast for drought stress and ecological functioning of coastal California endemic plant species. Journal of Biogeography 36:783-799.

Fraile, A., F. Escriu, M.A. Aranda, J.M. Malpica, A.J. Gibbs, and F. García-Arenal. 1997. A century of tobamovirus evolution in an Australian population of Nicotiana glauca. Journal of Virology 71:8316-8320.

GILL, K.M. 2014. Seasons of change: using seasonal morphological changes in Brodiaea corms to determine season of harvest from archaeobotanical remains. American Antiquity 79:638-654.

GiLL, K.M. 2015. Ancient plant use and the importance of geophytes among the Island Chumash of Santa Cruz Island, California. Doctoral dissertation, Department of Anthropology, University of California, Santa Barbara, CA.

GiLL, K.M. 2016. 10,000 years of geophyte use among the Island Chumash of the Northern Channel Islands. Fremontia 44:34-38.

Gill, K.M., J.M. Erlandson, K. Niessen, K. Hoppa, and D. MerRick. 2019. Where carbohydrates were key: reassessing the marginality of terrestrial plant resources on California's islands. In: K.M. Gill, M. Fauvelle, and J.M. Erlandson, editors, An archaeology of abundance: reevaluating the marginality of California's islands. University Press of Florida, Gainesville, FL.

GiLl, K.M., AND K.M. Hoppa. 2016. Evidence for an Island Chumash geophyte-based subsistence economy on the northern Channel Islands. Journal of California and Great Basin Anthropology 36:51-71.

Gleason, M.G., J.E. Caselle, C. Caldow, R. Galipeau, W. Heady, C. Laverty, A. Little, D. Mazurkiewicz, 
E. O'Brrne, D. Rosen, and S. Whitaker. 2018. Horizon scanning: survey and research priorities for coastal and marine systems of the northern Channel Islands, California. Western North American Naturalist 78:864-878.

Hanna, C., I. Naughton, C. Boser, R. Alarcon, K.-L.J. Hung, and D. Holway. 2015. Floral visitation by the Argentine ant reduces bee visitation and plant seed set. Ecology 96:222-230.

Herrmann, B., and S. Hummel, editors. 1994. Ancient DNA: recovery and analysis of genetic information from paleontological, archaeological, museum, medical, and forensic specimens. Springer-Verlag, New York, NY.

Hiers, J.K., R.J. Mitchell, A. Barnett, J.R. Walters, M. Mack, B. Williams, and R. Sutter. 2012. The dynamic reference concept: measuring restoration success in a rapidly changing no-analogue future. Ecological Restoration 30:27-36.

Higgs, E., D.A. Falk, A. Guerrini, M. Hall, J. Harris, R.J. Hobbs, S.T. Jackson, J.M. Rhemtulla, and W. Throop. 2014. The changing role of history in restoration ecology. Frontiers in Ecology and the Environment 12:499-506.

Hochberg, M., S. Junak, and R. Philbrick. 1980. Botanical study of Santa Cruz Island for The Nature Conservancy. Santa Barbara Botanic Garden, Santa Barbara, CA.

Hofman, C.A., AND T.C. Rick. 2018. Ancient biological invasions and island ecosystems: tracking translocations of wild plants and animals. Journal of Archaeological Research 26:65-115.

Holmes, M.W., T.T. Hammond, G.O.U. Wogan, R.E. Walsh, K. LaBarbera, E.A. WOMMack, F.M. MarTins, J.C. Crawford, K.L. Mack, L.M. Bloch, and M.W. NACHMAN. 2016. Natural history collections as windows on evolutionary processes. Molecular Ecology 25:864-881.

[IPCC] Intergovernmental Panel on Climate Change. 2014. Climate change 2014: synthesis report. Contribution of Working Groups I, II and III to the Fifth Assessment Report of the Intergovernmental Panel on Climate Change [Core Writing Team, R.K. Pachauri and L.A. Meyer, editors]. IPCC, Geneva, Switzerland. $151 \mathrm{pp}$.

Johnson, L., AND D. RoDriguEz. 2001. Terrestrial vegetation monitoring Channel Islands National Park 1996-2000 report. Channel Islands National Park Technical Report 01-06, National Park Service. 45 pp.

Johnstone, J.A., AnD T.E. DAwson. 2010. Climatic context and ecological implications of summer fog decline in the coast redwood region. Proceedings of the National Academy of Sciences 107:4533-4538.

Jones, J.A., S.A. JunaK, AND R.J. Paul. 1993. Progress in mapping vegetation on Santa Cruz Island and a preliminary analysis of relationships with environmental factors. Pages 97-104 in F.G. Hochberg, editor, Third California Islands Symposium: recent advances in research on the California islands. Santa Barbara Museum of Natural History, Santa Barbara, CA.

Junak, S., T. Ayers, R. Scott, D. Wilken, and D. Young. 1995. A flora of Santa Cruz Island. Santa Barbara Botanic Garden in collaboration with California Native Plant Society, Santa Barbara, CA. 397 pp.

KNAPP, J. In preparation. 2015 and 2016 rare plant surveys of Santa Cruz Island. Internal Report. The Nature Conservancy.
KNAPP, J., AND D. RoDRiguez. In preparation. 2015 Santa Cruz Island vegetation map.

Knudsen, K., And J. Kocourková. 2012. The annotated checklist of lichens, lichenicolous and allied fungi of Channel Islands National Park. Opuscula Philolichenum 11:145-302.

Knudsen, K., J.C. Lendemer, And J. Kocourková. 2014. Lecanora annularis (Lecanoraceae, Lecanorales), a new lichen species from the Channel Islands and the Central California Coast. Monographs of the Western North American Naturalist 7:221-224.

Langin, K.M., T.S. Sillett, W.C. Funk, S.A. Morrison, M.A. Desrosiers, and C.K. Ghalambor. 2015. Islands within an island: repeated adaptive divergence in a single population. Evolution 69:653-665.

LAvoIE, C. 2013. Biological collections in an ever changing world: herbaria as tools for biogeographical and environmental studies. Perspectives in Plant Ecology, Evolution and Systematics 15:68-76.

Lavoie, C., Y. Jodoin, D. Merlis, and A. Goursaud. 2007. How did common ragweed (Ambrosia artemisiifolia L.) spread in Quebec? A historical analysis using herbarium records. Journal of Biogeography 34:1751-1761.

Levermann, A., P.U. Clark, B. Marzeion, G.A. Milne, D. Pollard, V. Radic, and A. Robinson. 2013. The multimillennial sea-level commitment of global warming. Proceedings of the National Academy of Sciences USA 110:13745-13750.

Loarie S.R., B.E. Carter, K. Hayhoe, S. McMahon, R. Moe, C.A. Knight, and D.D. Ackerly. 2008. Climate change and the future of California's endemic flora. PLOS ONE 3:e2502.

McEachern, A.K. 1998. Vegetation monitoring sample design for East Santa Cruz Island. Letter to Superintendent, Channel Islands National Park from USGS-BRD Research Ecologist, Ventura, CA.

MCEACHERn, A.K. 2000. Tree and shrub community monitoring protocol for Channel Islands National Park, California. USGS Open-File Report 00-74. 9 pp.

McEachern, A.K., K.A. Chess, and K.G. Niessen. 2010. Field surveys of rare plants on Santa Cruz Island, California, 2003-2006: historical records and current distributions. U.S. Geological Survey Scientific Investigations Report 2009-5264. 34 pp.

McEachern, K., D. Wilken, and K. Chess. 1997, Inventory and monitoring of California islands candidate plant taxa. U.S. Geological Survey Open-File Report 00-73, Western Ecological Research Center, Sacramento, CA. 46 pp.

Millar, C.I., R.D. Westfall, and D.L. Delany. 2007. Response of high-elevation limber pine (Pinus flexilis) to multiyear droughts and 20th-century warming, Sierra Nevada, California, USA. Canadian Journal of Forest Research 37:2508-2520.

Miller-Rushing, A.J., R.B. Primack, D. Primack, and S. Mukunda. 2006. Photographs and herbarium specimens as tools to document phenological changes in response to global warming. American Journal of Botany 93:1667-1674.

Minnich, R. 1980. Vegetation of Santa Cruz and Santa Catalina Islands. Pages 123-137 in D.M. Power, editor, The California islands: proceedings of a multidiciplinary symposium. Santa Barbara Museum of Natural History, Santa Barbara, CA.

Morrison, S.A. 2007. Reducing risk and enhancing efficiency in non-native vertebrate removal efforts on 
islands: a 25-year multi-taxa retrospective from Santa Cruz Island, California. Pages 398-409 in G.W. Witmer, W.C. Pitt, and K.A. Fagerstone, editors, Managing vertebrate invasive species: proceedings of an international symposium. USDA/APHIS/WS, National Wildlife Research Center, Fort Collins, CO.

Morrison, S.A. 2011. Trophic considerations in eradicating multiple pests. Pages 208-212 in C.R. Veitch, M.N. Clout, and D.R. Towns, editors, Island invasives: eradication and management. IUCN, Gland, Switzerland.

Morrison, S.A., T.S. Sillett, W.C. Funk, C.K. GhalamBOR, AND T.C. RICK. 2017. Equipping the 22ndcentury historical ecologist. Trends in Ecology and Evolution 32:578-588.

Morrison, S.A., T.S. Sillett, W.C. Funk, C.K. GhalamBOR, AND T.C. RICK. 2018. California island rediscovery: building an archive to improve conservation today and equip the historical ecologist of tomorrow. Western North American Naturalist 78:837-851.

Perroy, R.L., B. Bookhagen, G.P. Anser, and O.A. CHADWICK. 2010. Comparison of gully erosion estimates using airborne and ground-based LiDAR on Santa Cruz Island, California. Geomorphology 118: 288-300.

Pesendorfer, M.B. 2014. Scatter-hoarding of acorns by Island Scrub-Jays. Doctoral dissertation, University of Nebraska, Lincoln, NE.

Pesendorfer, M.B., C.M. Baker, M. Stringer, E. McDonald-Madden, M. Bode, A.K. McEachern, S.A. Morrison, And T.S. Sillett. 2017. Oak habitat recovery on California's largest islands: scenarios for the role of corvid seed dispersal. Journal of Applied Ecology. https://doi.org/10.1111/1365-2664.13041

Pinter, N., and W.D. Vestal. 2005. El Nino-driven landsliding and post-grazing vegetative recovery, Santa Cruz Island, California. Journal of Geophysical Research 110: F2. https://doi.org/10.1029/2004JF 000203

Primack, D., C. Imbres, R.B. Primack, A.J. MillerRushing, and P. Del Tredici. 2004. Herbarium specimens demonstrate earlier flowering times in response to warming in Boston. American Journal of Botany 91:1260-1264.

Rastogi, B., A.P. Williams, D.T. Fischer, S.F. Iacobellis, K. McEachern, L. Carvalho, C. Jones, S.A. BagusKas, and C.J. Still. 2016. Spatial and temporal patterns of cloud cover and fog inundation in coastal California: ecological implications. Earth Interactions 20:1-19.

Rick, T.C., T.J. Braje, J.M. Erlandson, K.M. Gill, L. KiRn, AND L. MCLAREN-Dewey. 2018. Horizon scanning: survey and research priorities for cultural, historical, and paleobiological resources of Santa Cruz Island, California. Western North American Naturalist 78:852-863.

Rick, T.C., C.A. Hofman, and L.A. Reeder-Myers. 2019. Why translocate? Evaluating the evidence and reasons for ancient human introductions of wildlife to California's islands. In: K.M. Gill, M. Fauvelle, and J.M. Erlandson, editors, An archaeology of abundance: reevaluating the marginality of California's islands. University Press of Florida, Gainesville, FL.

Rick, T.C., T.S. Sillett, C.K. Ghalambor, C.A. Hofman, K. Ralls, R.S. Anderson, C.L. Boser, T.J. Braje, D.R. Cayan, R.T. Chesser, and P.W. Collins. 2014.
Ecological change on California's Channel Islands from the Pleistocene to the Anthropocene. BioScience 64:680-692.

Ristaino, J.B. 1998. The importance of archival and herbarium materials in understanding the role of oospores in late blight epidemics of the past. Phytopathology 88:1120-1130

Schoenherr, A.A., C.R. Feldmeth, and M.J. Emerson. 1999. Natural history of the islands of California. University of California Press, Berkeley, CA. 491 pp.

SCHUYLER, P.T. In preparation. Repeat photography documents four decades of change in Santa Cruz Island vegetation.

Staudinger, M.D., S.L. Carter, M.S. Cross, N.S. Dubois, J.E. Duffy, C. Enquist, R. Griffis, J.J. Hellmann, J.J. Lawler, J. O’Leary, and S.A. MorRISON. 2013. Biodiversity in a changing climate: a synthesis of current and projected trends in the US. Frontiers in Ecology and the Environment 11: $465-473$.

Suarez, A.V., AND N.D. Tsutsui. 2004. The value of museum collections for research and society. BioScience 54:66-74.

Sutter, R.D., S.B. Wainscott, J.R. Boetsch, C.J. Palmer, and D.J. Rugg. 2015. Practical guidance for integrating data management into long-term ecological monitoring projects. Wildlife Society Bulletin 39:451-463.

TaYLOR, J.W., AND E.C. SWANn. 1994. DNA from herbarium specimens. Pages 166-181 in B. Herrmann and S. Hummel, editors, Ancient DNA: recovery and analysis of genetic information from paleontological, archaeological, museum, medical, and forensic specimens. Springer, New York, NY.

Thorp, R.W., A.M. Wenner, and J.F. Barthell. 1994. Flowers visited by honey bees and native bees on Santa Cruz Island. Pages 259-286 in W.L. Halverson and G.J. Maender, editors, Fourth California Islands Symposium: update on the status of resources. Santa Barbara Museum of Natural History, Santa Barbara, CA.

Thorp, R.W., A.M. Wenner, and J.F. Barthell. 2000. Pollen and nectar source overlap among bees on Santa Cruz Island. Pages 261-268 in D.R. Brown, K.L. Mitchell, and H.W. Chaney, editors, Fifth California Islands Symposium. MBC Applied Environmental Sciences, Costa Mesa, CA.

[USFWS] United States Fish and Wildlife Service. 2012. Draft recovery plan for four subspecies of island fox (Urocyon littoralis). U.S. Fish and Wildlife Service, Sacramento, CA. 106 pp. + appendixes.

Van Vuren, D., AND B.E. CoblentZ. 1987. Some ecological effects of feral sheep on Santa Cruz Island, California. Biological Conservation 41:253-268.

Walter, H.S., AND L.A. TAHA. 2000. Regeneration of bishop pine (Pinus muricata) in the absence and presence of fire: a case study from Santa Cruz Island, California. Pages 172-181 in D.R. Browne, K.L. Mitchell, and H.W. Chaney, editors, Proceedings of the Fifth California Islands Symposium. MBC Applied Environmental Sciences, Costa Mesa, CA.

Wentje, W. 1994. Response of a bishop pine (Pinus muricata) population to removal of feral sheep on Santa Cruz Island, California. Pages 331-340 in W.L. Halvorson and G.J. Maender, editors, The Fourth California Islands Symposium: update on the status 
of resources. Santa Barbara Museum of Natural History, Santa Barbara, CA.

Weigand, P.W., EDITOR. 1998. Contributions to the geology of the Northern Channel Islands, Southern California. Pacific Section, American Association of Petroleum Geologists, Bakersfield, CA. 196 pp.

Williams, A.P., R.E. Schwartz, S. Lacobellis, R. Seager, B.I. Cook, C.J. Still, G. Husak, and J. Michaelsen. 2015. Urbanization causes increased cloud-base height and decreased fog in coastal southern California. Geophysical Research Letters 42:1527-1536.

Williams, A.P., C.J. Still, D.T. Fischer, and S.L. LEavitT. 2008. The influence of summertime fog and overcast clouds on the growth of a coastal Californian pine: a tree-ring study. Oecologia 156:601-611.
Williams, J.W., AND S.T. Jackson. 2007. Novel climates, no analog communities, and ecological surprises. Frontiers in Ecology and the Environment 5: $475-482$.

WoODWARD, F.I. 1987. Stomatal numbers are sensitive to increases in $\mathrm{CO}_{2}$ from pre-industrial levels. Nature 327:617-618.

Received 8 March 2017

Revised 6 June 2018

Accepted 6 June 2018

Published online 5 November 2018 